University for Business and Technology in Kosovo

UBT Knowledge Center

Oct 28th, 2:00 PM - 3:30 PM

\title{
The effect of elevated temperature on the lightweight concrete containing waste PET aggregate
}

\section{Semiha Akçaözoğlu}

Nigde Ömer Halisdemir University, sakcaozoglu@gmail.com

Follow this and additional works at: https://knowledgecenter.ubt-uni.net/conference

Part of the Civil Engineering Commons

\section{Recommended Citation}

Akçaözoğlu, Semiha, "The effect of elevated temperature on the lightweight concrete containing waste PET aggregate" (2017). UBT International Conference. 44.

https://knowledgecenter.ubt-uni.net/conference/2017/all-events/44

This Event is brought to you for free and open access by the Publication and Journals at UBT Knowledge Center. It has been accepted for inclusion in UBT International Conference by an authorized administrator of UBT Knowledge Center. For more information, please contact knowledge.center@ubt-uni.net. 


\title{
The effect of elevated temperature on the lightweight concrete containing waste PET aggregate
}

\author{
Semiha Akçaözoğlu \\ Department of Architecture, Faculty of Architecture, Nigde Ömer Halisdemir \\ University, Nigde, Turkey \\ sakcaozoglu@gmail.com, sakcaozoglu@ohu.edu.tr
}

\begin{abstract}
In this study, the effect of waste PET as lightweight aggregate (WPLA) replacement with conventional aggregate on the some physical and mechanical properties and residual compressive strength of concrete was investigated. For this purpose, five different mixtures were prepared (the reference mixture and four WPLA mixtures including 30\%, 40\%, $50 \%$ and $60 \%$ waste PET aggregate by volume). The fresh and dry unit weights, compressive strengths, flexural-tensile strengths, water absorption and porosity ratios of the mixtures were measured. In addition the specimens exposed to elevated temperatures at 150,300 and $450{ }^{\circ} \mathrm{C}$ and the residual compressive strengths were measured. Test results indicated that the unit weight, compressive strength and flexural-tensile strength of the specimens decreased as the amount of WPLA increased in concrete. After exposing to elevated temperature, WPLA mixtures retained their structural integrity and compressive strengths at $150{ }^{\circ} \mathrm{C}$ and $300{ }^{\circ} \mathrm{C}$. However there was a significant decrease in the residual compressive strength values of WPLA mixtures at $450{ }^{\circ} \mathrm{C}$.
\end{abstract}

Keywords: Waste PET aggregate, residual compressive strength, elevated temperature, recycling.

\section{Introduction}

PET is one of the most widely used plastics in the packaging industry because of its lightweight and easiness of handling and storage [1]. Since the development in the 1973, the consumption of PET has been increasing consistently and considerably. Global PET resin production capacity is 27.8 tons in 2015 [2]. And it is forecasted that by 2020 its production will be approximately 73.39 million metric tons [3]. Approximately 600 billion bottles are discarded every year all around the world and only $47 \%$ is collected [4].

Due to the rapid increase in the use of PET bottles, solid waste problem has been raised. Disposing off the non-biodegradable used PET bottles has become a major concern. The exponential growth in PET waste from packaging incited a search for alternative means of recycling. Using waste PET bottles as aggregate in concretes or mortars has attracted the interest of researchers for a recycling application. During the past twenty years the numbers of studies have been carried out about waste PET aggregate concrete increased among other studies about the recycling of plastic wastes in the production. The major advantage of using waste PET bottles as aggregates is the reduction of the self-weight of the concrete because of its low unit weight [5].

Several experimental studies have addressed the technical viability of incorporating waste PET aggregate in concrete, investigating the effects of such incorporation on the mechanical and durability properties of concrete [6-11] However limited studies have been carried out for the effect of elevated temperature on concrete containing replacement of natural aggregates by waste PET aggregate $[12,13]$. 
The main aim of this study is to investigate the behavior of concretes containing waste PET aggregate (WPLA) when subjected to elevated temperatures, in term of residual compressive strength. For this purpose, five different mixtures were produced: a reference mixture and four concrete mixtures incorporating $30 \%$ to $60 \%$ of four different ratios of WPLA as a replacement of natural aggregates. All concrete mixtures were exposed for $2 \mathrm{~h}$ to furnace at temperatures of $150{ }^{\circ} \mathrm{C}, 300{ }^{\circ} \mathrm{C}, 450{ }^{\circ} \mathrm{C}$ and $600{ }^{\circ} \mathrm{C}$. After exposing to elevated temperatures, the residual compressive strengths of the specimens were compared with unheated reference mixtures. In addition the fresh and dry unit weights, compressive strengths, flexural-tensile strengths, water absorption and porosity ratios of the WPLA mixtures were also measured.

\section{Materials}

Ordinary Portland Cement CEM I 42.5 R (PC) conforming to requirements of TS EN 197-1 [14] was used for concrete mixture preparing. The specific surface area of PC measured with Blaine method was $3670 \mathrm{~cm}^{2} / \mathrm{g}$, and the specific weight of the PC was $3.10 \mathrm{~g} / \mathrm{cm}^{3}$. The initial and final setting times of the cement were 143 and $200 \mathrm{~min}$, respectively. The 28-day compressive strength of PC according to TS EN 196-1 [15] was $52.7 \mathrm{MPa}$. Chemical oxide composition of PC is presented in Table 1 .

OTable 1. Chemical properties of PC

\begin{tabular}{lccccccccc}
\hline Oxide $(\%)$ & $\mathrm{SiO}_{2}$ & $\mathrm{Al}_{2} \mathrm{O}_{3}$ & $\mathrm{Fe}_{2} \mathrm{O}_{3}$ & $\mathrm{CaO}$ & $\mathrm{MgO}$ & $\mathrm{SO}_{3}$ & $\mathrm{Na}_{2} \mathrm{O}$ & $\mathrm{K}_{2} \mathrm{O}$ & LOI \\
PC & 19.48 & 5.062 & 2.467 & 62.46 & 2.94 & 3.602 & 0.54 & 0.717 & 3.66 \\
\hline
\end{tabular}

Uncrushed, quartzitic natural sand with maximum size of $4 \mathrm{~mm}$ and crushed basaltic coarse aggregate with maximum size of $16 \mathrm{~mm}$ in accordance with TS $706 \mathrm{EN} 12620+\mathrm{A} 1$ [27] were used in the mixture. The specific weights of fine and coarse aggregates at saturated surface dry condition were $2.45 \mathrm{~g} / \mathrm{cm}^{3}$ and $2.57 \mathrm{~g} / \mathrm{cm}^{3}$, respectively. The water absorption values of fine and coarse aggregates were $2.5 \%$ and $2.0 \%$, respectively [16]. The grading of aggregates is presented in Table 2 with the standard specification.

Table 2. Aggregate grading with standard limit

\begin{tabular}{lcccc}
\hline \multirow{2}{*}{$\begin{array}{l}\text { Sieve size } \\
(\mathrm{mm})\end{array}$} & \multicolumn{4}{c}{ Passed (\%) } \\
\cline { 2 - 5 } & $\begin{array}{c}\text { lower limit } \\
{[17]}\end{array}$ & $\begin{array}{c}\text { medium limit } \\
{[17]}\end{array}$ & $\begin{array}{c}\text { upper limit } \\
{[17]}\end{array}$ & Aggregate used \\
\hline 16 & 100 & 100 & 100 & 100 \\
11.2 & 98 & 99 & 100 & 99.3 \\
8 & 85 & 92 & 99 & 85.0 \\
4 & 62 & 75 & 88 & 65.3 \\
2 & 40 & 56 & 72 & 46.5 \\
1 & 23 & 39 & 55 & 31.5 \\
0.5 & 13 & 26 & 38 & 17.0 \\
0.25 & 7 & 15 & 22 & 8.5 \\
0.15 & 3 & 8 & 12 & 3.5 \\
0.063 & 1 & 3 & 5 & 1.2 \\
\hline
\end{tabular}


The waste PET bottle granules used as aggregate (WPLA) was supplied from SASA PET Bottles Plant, in Adana, in Turkey. The plant collects waste PET bottles, washes them and then crushes in granules. After sifting through various sieves, waste PET granules are used for making fiber. In this study, PET granules are used which are too small to be used in making fibers and described as "undersized». Maximum size and specific weight of WPLA were $4 \mathrm{~mm}$ and $1.27 \mathrm{~g} / \mathrm{cm}^{3}$, respectively (Fig 1). The grading of the WPLA is presented in Table 3.

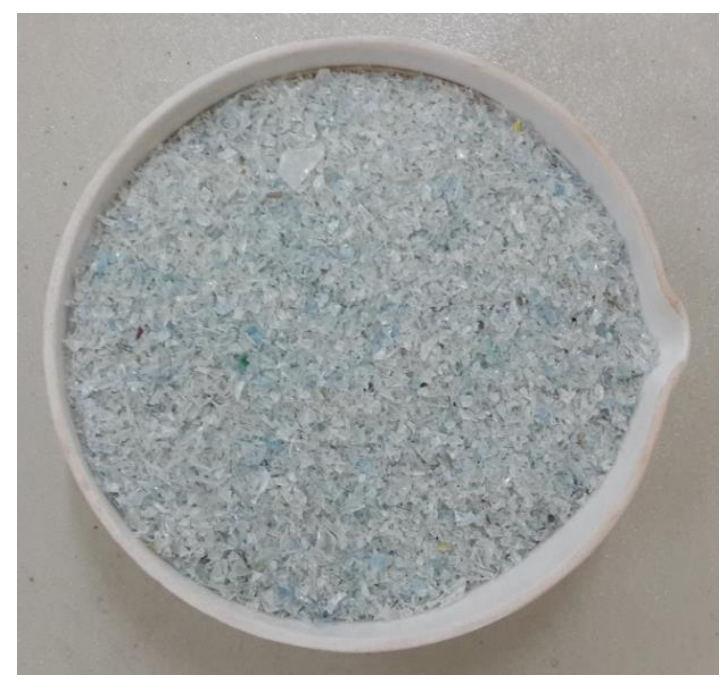

Fig. 1. The granules of PET used as aggregate (WPLA)

Table 3. Waste PET lightweight aggregate (WPLA) gradations

\begin{tabular}{lll}
\hline \multicolumn{2}{l}{ particle size range $(\mathrm{mm})$} & $\begin{array}{l}\text { PET } \\
(\%)\end{array}$ \\
\hline $\mathrm{d}_{\max }$ & $\mathrm{d}_{\min }$ & 15 \\
4 & 2 & 67 \\
2 & 1 & 16 \\
1 & 0.5 & 2 \\
0.5 & 0.25 & 0 \\
0.25 & 0 & 100 \\
\hline Total & & \\
\hline
\end{tabular}

Polycarboxylicetherbasedsuperplasticizer (SP) according to TS EN 934-2 [18] was used to improve workabilityof the mixtures. The specific weight of superplasticizer was ranged between $1.023-1.063 \mathrm{~g} / \mathrm{cm}^{3}$.

\section{Mixture Properties and Testing Methods}

Reference mixture design was made with according to absolute volume method given by TS 802 [19]. The water-cement(w/c) ratio usedin mixtures was chosen as 0.50 . Cement content was kept constant for per cubic meter, $500 \mathrm{~kg} / \mathrm{m}^{3}$. The approximate air content of fresh concrete 
mixture was $1 \%$ estimated by using total aggregate granulometry. The volume of total aggregate was determined using absolute volume method, then, weight of aggregate was calculated using unit weight of aggregate. For each concrete mixture of a cubic meter, approximate concrete composition is given in Table 4. Substitution ratios were 30\%, 40\%, $50 \%$ and $60 \%$ by volume.

Table 4. Approximate concrete composition for a cubic meter

\begin{tabular}{|c|c|c|c|c|c|c|c|}
\hline \multirow[b]{2}{*}{ Mixture } & \multirow{2}{*}{$\begin{array}{c}\text { WPLA } \\
\text { amount } \\
(\%)\end{array}$} & \multicolumn{6}{|c|}{ Unit weigth $\left(\mathrm{kg} / \mathrm{m}^{3}\right)$} \\
\hline & & NPC & Water & $\begin{array}{l}\text { Coarse } \\
\text { Aggregate }\end{array}$ & $\begin{array}{l}\text { Fine } \\
\text { Aggregate }\end{array}$ & WPLA & SP \\
\hline M0 & 0 & 500 & 250 & 575 & 877 & 0 & 0 \\
\hline M1 & 30 & 500 & 250 & 402 & 615 & 218 & 2 \\
\hline M2 & 40 & 500 & 250 & 345 & 526 & 292 & 5 \\
\hline M3 & 50 & 500 & 250 & 288 & 438 & 365 & 6 \\
\hline M4 & 60 & 500 & 250 & 230 & 350 & 437 & 7.5 \\
\hline
\end{tabular}

Cubic specimens with a $100 \mathrm{~mm}$ side were cast and used for measurement of unit weight, compressive strength and water absorption and porosity ratios. Prismatic specimens with the dimensions of 500x 100x100 mm were cast and used for flexural and tensile strength test. All the specimens were de-molded after $24 \mathrm{~h}$ and cured in lime saturated water at $20 \pm 2^{\circ} \mathrm{C}$ for 28 days. Later, the specimens were removed from water and kept in laboratory conditions $\left(20 \pm 2^{\circ} \mathrm{C}\right.$ and $45 \pm 5 \%$ relative humidity) for eleven months.

The compressive strength of concrete specimens was measured according to TS EN 12390-3 [20]. Experimentswere carried out at uniaxial compression instrument with a capacity of3000KN andloading rate was $0.5 \mathrm{MPa} / \mathrm{s}$ (Fig. 2). Three specimens were used in compressive strength measurement for each mixture, and the average of three measurements of specimens was presented and discussed in the study.

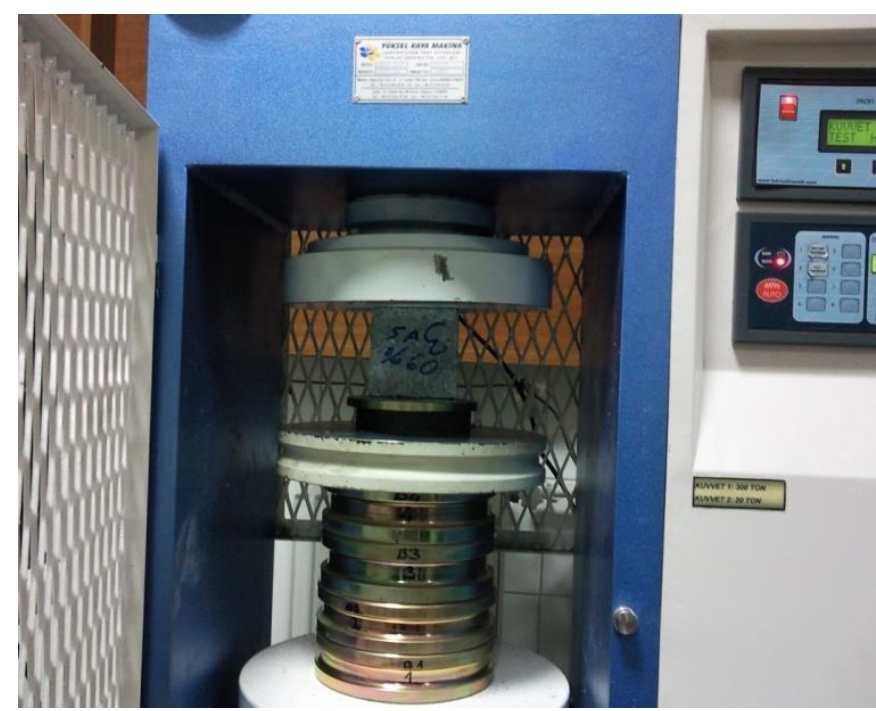

Fig. 2. Compressive strength test 
The flexural-tensile strength measurements were performed on the three prismatic specimens by three points loading test (Fig. 3.) by using the test methods according to TS EN 12390-5 [21].

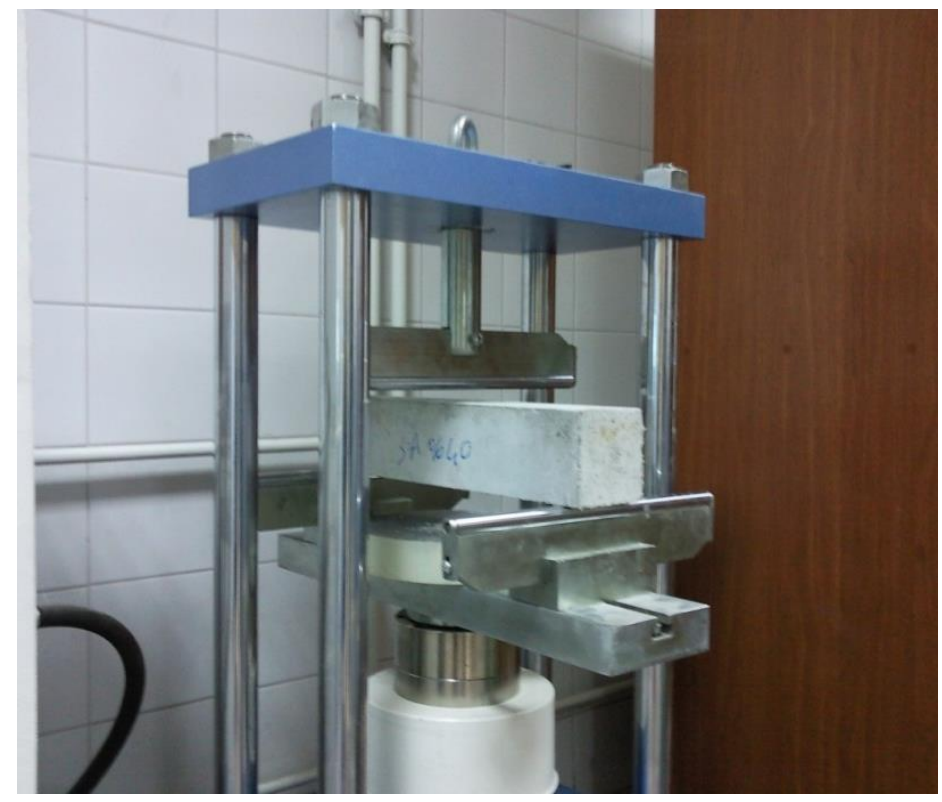

Fig. 3. Flexural-tensile strength

The water absorption, porosity ratios and unit weight measurements were performed on cubic specimens with size of $100 \mathrm{~mm}$ at 12 months of curing in conformity with TS 3624 [22]. The fresh unit weights of the mixtures were also measured. The values were expressed by taking the average of three test results.

The elevated temperature resistance tests of the specimens were performed on cubic specimens with size of $100 \mathrm{~mm}$. From each mixture three specimens were exposed to 150,300 and $450{ }^{\circ} \mathrm{C}$ temperatures for $2 \mathrm{~h}$ in furnace. The temperature-time graph of the furnace is given Figure 4. Afterwards the specimens exposed to elevated temperatures were cooled in laboratory conditions at $20 \pm 2{ }^{\circ} \mathrm{C}$. After the cooling period to room temperature, the specimens were subjected to compressive strength test according to TS EN 12390-5 [21]. Three specimens were tested at each stage and average values were reported. The test results were compared with those of unheated concrete $\left(20^{\circ} \mathrm{C}\right)$. 


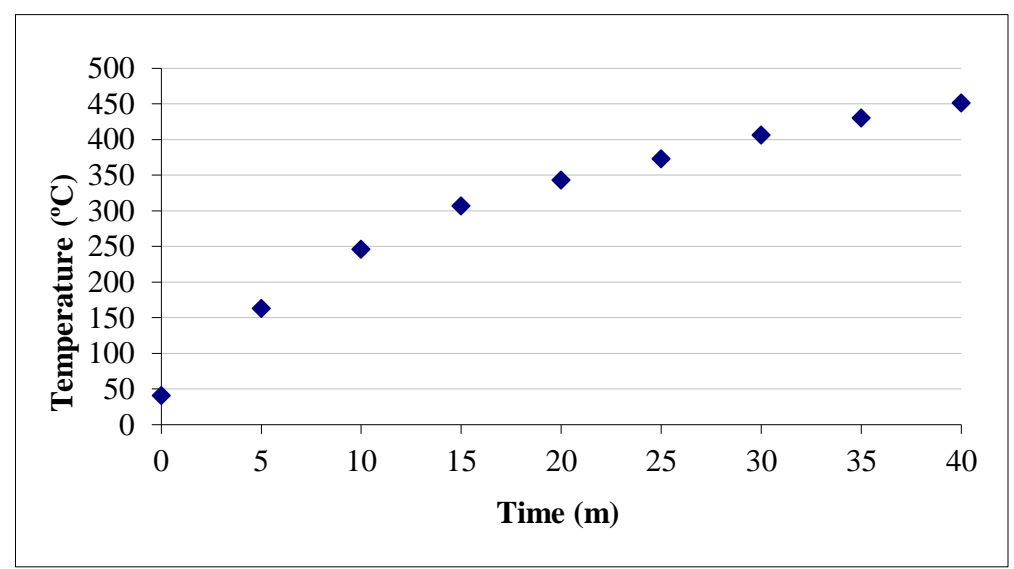

Fig. 4. The relationship of time-temperature of the furnace

\section{Results and Discussion}

\section{Unit Weight}

The fresh and 365-day dry unit weights of WPLA mixtures are presented in Table 5. The unit weights of all specimens decreased in course of time due to the evaporation of free water. The dry unit weight values of WPLA mixtures were between 1.48 and $1.58 \mathrm{~g} / \mathrm{cm}^{3}$. These were within the limits of unit weight specified at ACI 213R-14 [23] for lightweight structural concrete.

Table 5. Fresh and dry unit weights of specimens

\begin{tabular}{cccc}
\hline \multirow{2}{*}{ Mixture } & \multirow{2}{*}{ WPLA amount $(\%)$} & \multicolumn{2}{c}{ Unit weight $\left(\mathrm{g} / \mathrm{cm}^{3}\right)$} \\
\cline { 3 - 4 } & & Fresh & Dry \\
\hline M0 & 0 & 2.24 & 2.07 \\
M1 & 30 & 1.97 & 1.58 \\
M2 & 40 & 1.80 & 1.56 \\
M3 & 50 & 1.77 & 1.55 \\
M4 & 60 & 1.59 & 1.48 \\
\hline
\end{tabular}

The fresh and dry unit weights of WPLA mixtures decreased as the amount of PET aggregate increased in concrete mixture. The reduction of the unit weights can be explained by the low specific weight of PET plastic $\left(1.27 \mathrm{~g} / \mathrm{cm}^{3}\right)$ compared to the conventional aggregate $\left(2.45 \mathrm{~g} / \mathrm{cm}^{3}\right.$ and $2.57 \mathrm{~g} / \mathrm{cm}^{3}$ ).

\section{Compressive Strength}


The 365-day compressive strength values of the mixtures measured in the laboratory were presented in Table 6. It is observed from Table 6 that the compressive strength of reference mixture (M0) decreased due to the WPLA addition. Reduction rate increased depending on increasing PET aggregate amount in the mixtures. Reduction rates of compressive strengths of M1, M2, M3 and M4 based on control mixture (M0) were 53.4\%, 61.9\%, 69.6\% and $85.1 \%$, respectively. The minimum compressive strength value of the specimens was observed at M4 mixture (containing \%60 PET aggregate). Nevertheless, the compressive strength values of M1, M2 and M3 mixture were close to each other. And the M1 and M2 mixtures (containing 30\% and $40 \%$ PET aggregate) were drop into structural lightweight concrete category [23].

Table 6. Compressive strengths of the mixtures

\begin{tabular}{cccc}
\hline $\begin{array}{c}\text { Mixtur } \\
\text { e }\end{array}$ & $\begin{array}{c}\text { WPLA } \\
\text { amount }(\%)\end{array}$ & $\begin{array}{c}\text { 365-day Compressive } \\
\text { Strength (MPa) }\end{array}$ & $\begin{array}{c}\text { Reduction rate } \\
(\%)\end{array}$ \\
\hline M0 & 0 & 50.4 & - \\
M1 & 30 & 23.5 & 53.4 \\
M2 & 40 & 19.2 & 61.9 \\
M3 & 50 & 15.3 & 69.6 \\
M4 & 60 & 7.5 & 85.1 \\
\hline
\end{tabular}

The influence of WPLA amount on the compressive strength values of the mixtures is presented in Figure 5 as graphic. It is observed from Fig. 5 that the compressive strength of specimens decreased depending on increment of WPLA amount replaced with conventional aggregate. It was thought that there are two reasons of this result. The first reason is that the strength of WPLA is lower than that of natural aggregate. The other reason for this situation is that the connection between WPLA and cement paste did not as strong asthe bond betweennaturalaggregate and cement paste $[6,7,9]$.

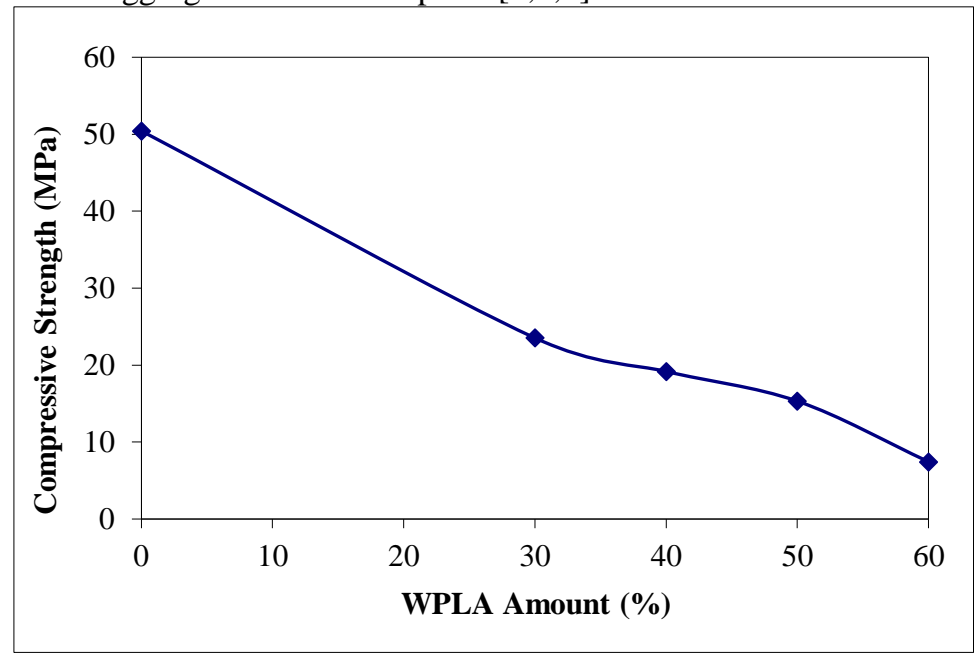

Fig. 5. The influence of WPLA amount on the compressive strength values of the mixtures 


\section{Flexural-tensile Strength}

The 365-day flexural-tensile strength values of the mixtures are presented in Table 7. And the effect of WPLA amount on the flexural-tensile strength of the mixtures is presented in Fig. 6. It was observed from Table 7 and Fig. 6 that the flexural-tensile strength of the mixtures decreased depending on increasing WPLA amount. The flexural-tensile strength of the M1 mixture (containing 30\% PET aggregate) was lower than reference mixture (M0) about $43.3 \%$.

Table 7. Flexural-tensile strengths of the mixtures

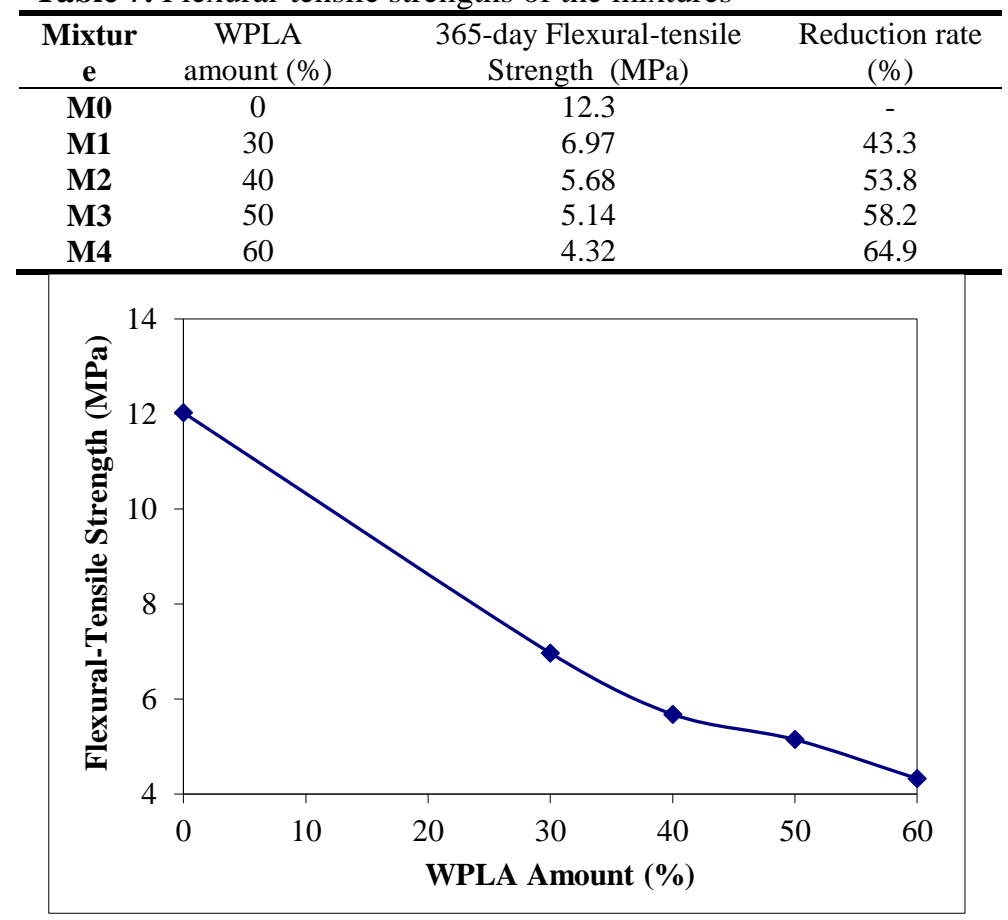

Fig. 6. The influence of WPLA amount on the flexural-tensile strength values of the mixtures

The relationship between the compressive strength and flexural-tensile strength of the mixtures is presented in Figure 7. The correlation coefficient of relationship was found to be 0.989 . From this result, it is concluded that a linear relationship between compressive strength and flexuraltensile strength of specimens existed. 


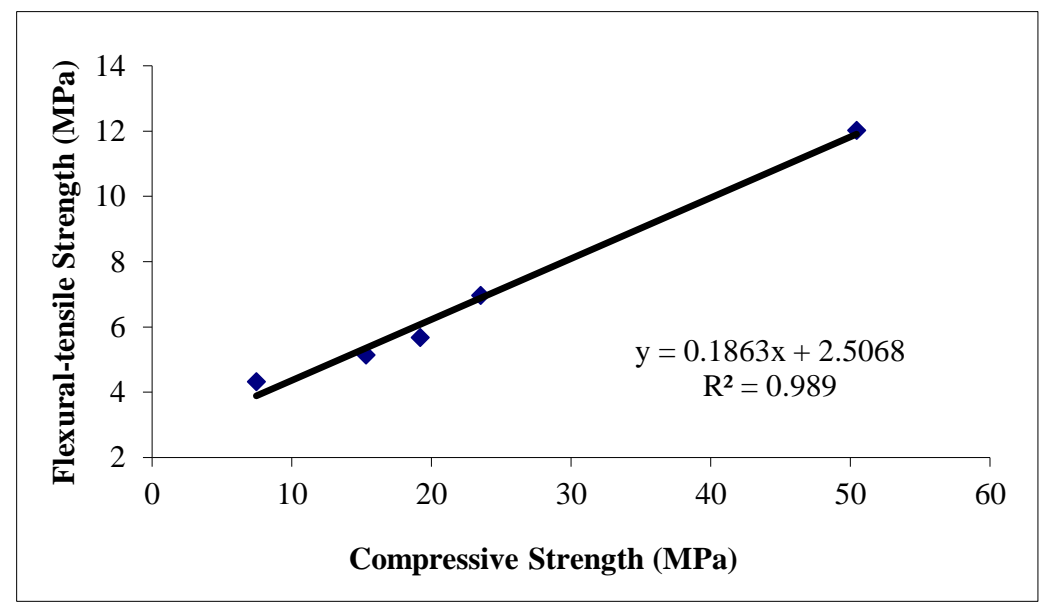

Fig. 7. The relationship between the compressive strength and flexural-tensile strength of the mixtures

\section{Water Absorption and Porosity Ratio}

The water absorption and porosity ratios of the specimens at the age of 365 days are given in Table 8.

Table 8. Water absorption and porosity ratios of the mixtures

\begin{tabular}{cccc}
\hline $\begin{array}{c}\text { Mixtur } \\
\text { e }\end{array}$ & $\begin{array}{c}\text { WPLA } \\
\text { amount }(\%)\end{array}$ & Water absorption $(\%)$ & Porosity (\%) \\
\hline M0 & 0 & 5.62 & 12.75 \\
M1 & 30 & 9.32 & 20.79 \\
M2 & 40 & 10.16 & 24.64 \\
M3 & 50 & 10.38 & 27.04 \\
M4 & 60 & 13.27 & 31.07 \\
\hline
\end{tabular}

The water absorption ratio of the reference mixture (M0) was $5.62 \%$. This value increased depending on increasing WPLA amount in the mixtures and the water absorption ratio of M4 mixture (containing 60\% WPLA aggregate) increased to $13.27 \%$. In addition, increasing WPLA amount caused more porous structure at all mixtures. The porosity ratio of M0 increased from $12.75 \%$ to $31.07 \%$, when the WPLA amount was $60 \%$ (M4). Increasing porosity ratios of the mixtures also caused to increase at water absorption ratios of the mixtures. Increasing WPLA amount in the mixtures adversely affected the workability. It made the casting to the molds difficult. Therefore, the voids in the mixtures increased and the water permeability property of the specimens increased.

However, the water absorption values of the WPLA mixtures were between 9.32-13.27\%. It was stated in the literature that lightweight concrete absorbs more water than normal concrete and its water absorption ratio is between 12-22\% [24]. The water absorption ratios of the mixtures were found to be within the water absorption limits of lightweight concrete. 


\section{Residual Compressive Strength}

The mixtures produced in this research were exposed to the elevated temperatures at 150,300, and $450{ }^{\circ} \mathrm{C}$ and then their residual compressive strength values were determined. The residual compressive strengths of mixtures are presented in Table 9.

Table 9. The residual compressive strengths of the mixtures (MPa)

\begin{tabular}{cccccc}
\hline & \multicolumn{4}{c}{ Residual compressive strength (MPa) } \\
\hline $\begin{array}{c}\text { Mixtu } \\
\text { re }\end{array}$ & $\begin{array}{c}\text { WPLA } \\
\text { amount }(\%)\end{array}$ & $\begin{array}{c}\text { Initial compressive } \\
\text { strength (MPa) }\end{array}$ & $150{ }^{\circ} \mathrm{C}$ & $300{ }^{\circ} \mathrm{C}$ & $450{ }^{\circ} \mathrm{C}$ \\
\hline M0 & 0 & 50.4 & 52.0 & 50.6 & 46.8 \\
M1 & 30 & 23.5 & 22.6 & 22.0 & 12.8 \\
M2 & 40 & 19.2 & 18.1 & 17.4 & 10.0 \\
M3 & 50 & 15.3 & 14.9 & 13.8 & 6.3 \\
M4 & 60 & 7.5 & 10.8 & 8.6 & 1.9 \\
\hline
\end{tabular}

It was seen from Table 9 that the residual compressive strength values of the specimens decreased depending on increasing temperature. At $450{ }^{\circ} \mathrm{C}$, the decreasing ratios of $\mathrm{M} 0, \mathrm{M} 1$, M2, M3 and M4 mixtures to initial compressive strength were $7.2 \%, 45.6 \%, 47.8 \%, 58.6 \%$ and $74.5 \%$, respectively. The residual compressive strength values decreased depending on increasing WPLA amount in the mixtures.

From this result it was thought that WPLA did not resistant to the high temperature effect. Especially, the specimens containing $60 \%$ PET aggregate were deformed after the temperature of $450{ }^{\circ} \mathrm{C}$. The effect of elevated temperature on the residual compressive strength of the specimens is presented in Figure 8.

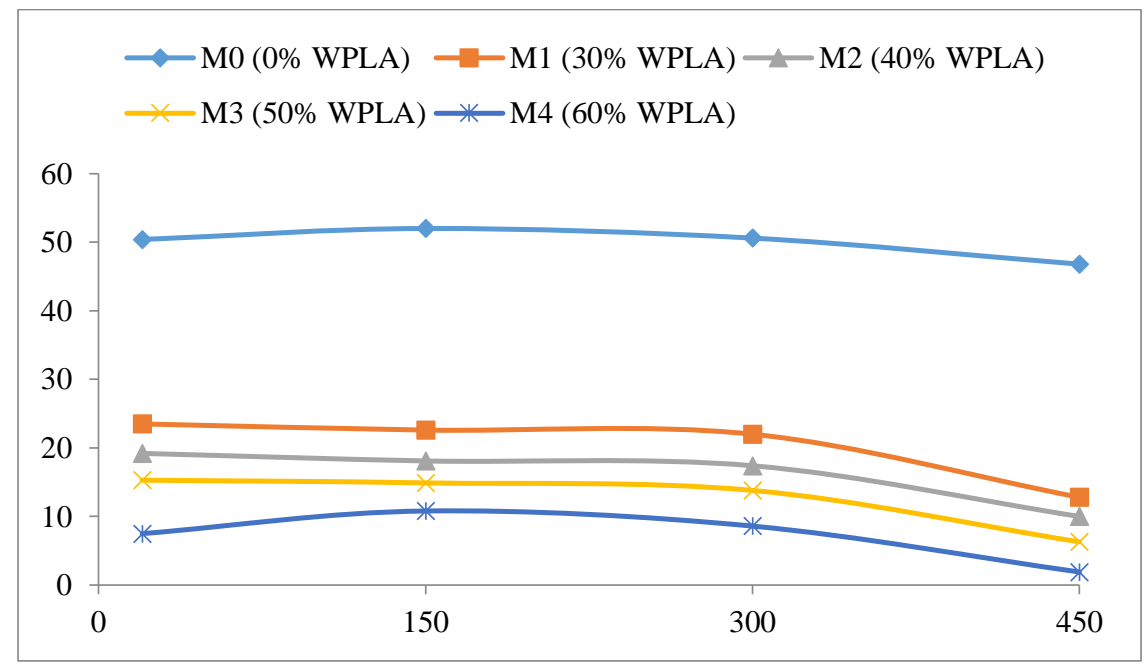

Fig. 8. The effect of elevated temperature on the residual compressive strength of the mixtures 
It is clearly seen from Fig. 8 that the resistance of WPLA mixtures against elevated temperature was lower than that of reference mixture containing natural aggregate.

It is observed that all specimens retained their part of strengths at temperatures of $150{ }^{\circ} \mathrm{C}$ and $300{ }^{\circ} \mathrm{C}$. However there was a significant decrease in the residual compressive strength values of WPLA mixtures at $450{ }^{\circ} \mathrm{C}$.

This is due to the fact that the PET begins to melt after $260-280{ }^{\circ} \mathrm{C}$, and the PET aggregates in the specimens melted from about $300{ }^{\circ} \mathrm{C}$ (Fig. 9-11). As can be seen from the pictures, there was no change in the appearances of the reference mixture and WPLA mixtures exposed to 150 ${ }^{\circ} \mathrm{C}$ and $300{ }^{\circ} \mathrm{C}$. However, while reference concrete (M0) retained the structural integrity after exposed to $450{ }^{\circ} \mathrm{C}$, deteriorations of the PET aggregate specimens were also observed very clearly as the WPLA amount in the mixtures increasing.

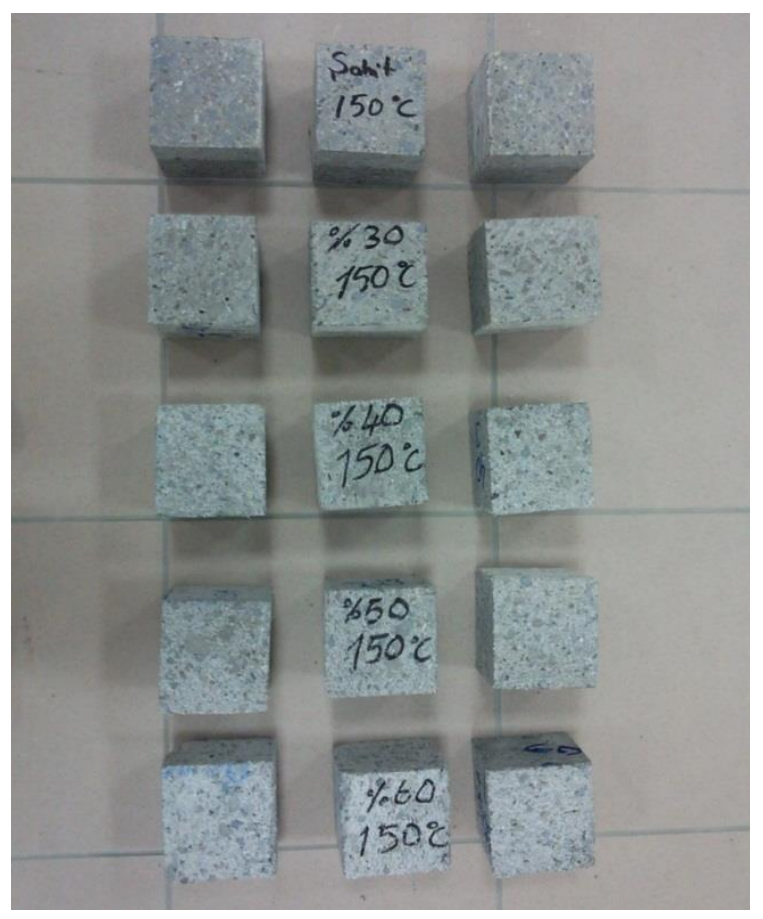

Fig. 9. The mixtures exposed to $150^{\circ} \mathrm{C}$ 


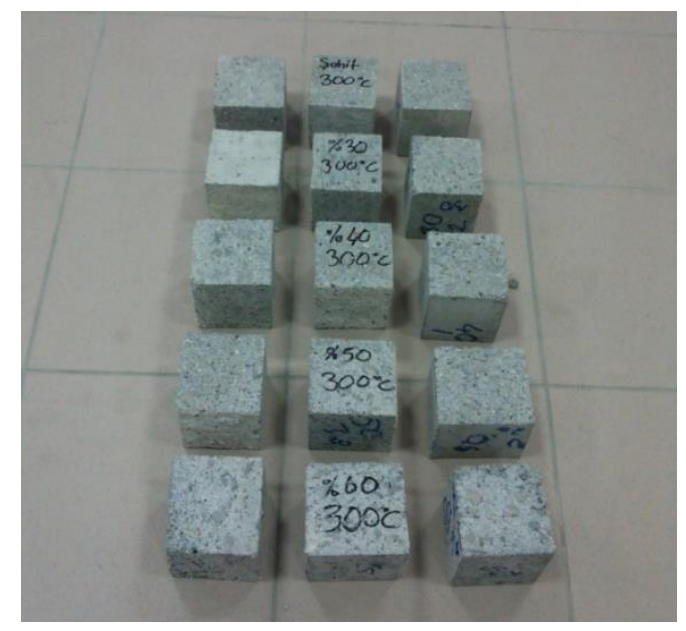

Fig. 10. The mixtures exposed to $300{ }^{\circ} \mathrm{C}$

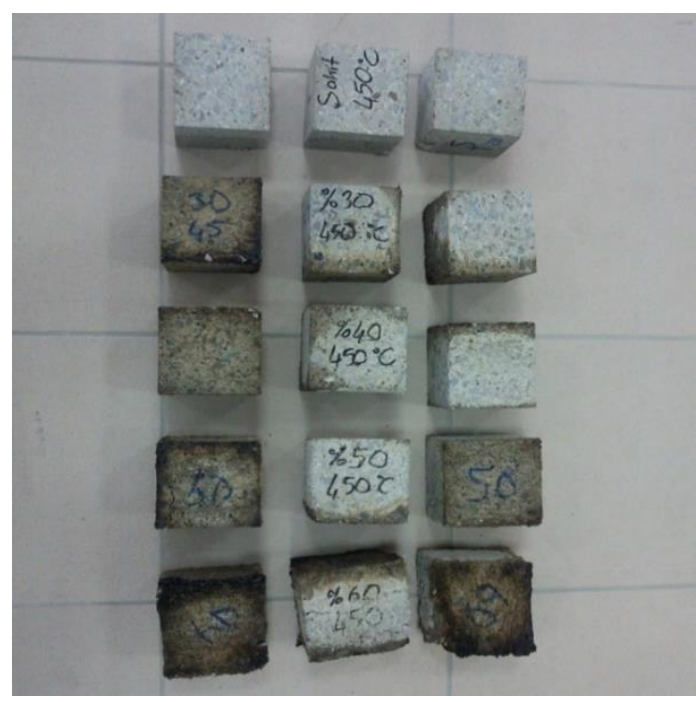

Fig. 11. The mixtures exposed to $450{ }^{\circ} \mathrm{C}$

\section{Conclusions}

- The mixtures containing 30 and 40\% WPLA were drop into structural lightweight concrete category.

- The water absorption ratios of the WPLA mixtures between the lightweight concrete limits.

- The compressive strength of specimens decreased as the amount of WPLA increased in the mixture. The main reason for this situation could be the 
adherence between WPLA and cement paste that might not be as strong asthe bond betweennaturalaggregate and cement paste.

- The residual compressive strength values decreased depending on increasing WPLA in the mixtures. The waste PET aggregate did not resistant to the high temperature effect. All mixtures retained their structural integrity and compressive strength at temperatures of $150{ }^{\circ} \mathrm{C}$ and $300^{\circ} \mathrm{C}$. However there was a significant decrease in the residual compressive strength values of WPLA mixtures after exposed to $450^{\circ} \mathrm{C}$.

- Based on the experimental study, the use of WPLA in concrete composites has a potential to reduce the death weight of concrete, thus, it could be helpful in the design of an earthquake resistant building.In addition, using WPLA in the construction applications can be helpful for the environmental concern. However, before using WPLA in concrete production, its behavior against to elevated temperature must be taken into account and additional fire protection measures must be taken in structural applications.

\section{References}

1. Rahmani, E., Dehestani, M., Beygi, M.H.A., Allahyari H., Nikbin, I.M.: On the Mechanical Properties of Concrete Containing Waste PET Particles. Constr. Build. Mater. 47 (2013) 1302-1308

2. https://www.plasticsinsight.com/global-pet-resin-production-capacity/ (07.09.2017)

3. https://www.statista.com/statistics/650191/global-polyethylene-terephthalateproduction-outlook/ (07.09.2017)

4. Dutta, S., Nadaf, M.B., Mandal, J.N.: An Overview on the Use of Waste Plastic Bottles and Fly Ash in Civil Engineering Applications. Procedia Environ. Sci. 35 (2016) 681-691

5. Islam M.J., , Meherier, M.S., Islam, A.K.M. R.: Effects of Waste PET as Coarse Aggregate on the Fresh and Harden Properties of Concrete. Constr. Build. Mater. 125 (2016) 946-951

6. Akçaözoğlu, S., Atiş, C.D., Akçaözoğlu, K.: An Investigation on the use of Shredded Waste PET Bottles as Aggregate in Lightweight Concrete. Waste Manage. 30-2 (2010) 285-290

7. Akçaözoğlu, S., Atiş, C.D.: Effect of Granulated Blast Furnace Slag and Fly Ash Addition on the Strength Properties of Lightweight Mortars Containing Waste PET Aggregates. Constr. Build. Mater 25 (2011) 4052-4058

8. Akçaözoğlu, S., Akçaözoğlu, K., Atiş, C.D.: Thermal Conductivity, Compressive Strength and Ultrasonic Wave Velocity of Cementitious Composite Containing Waste PET Lightweight Aggregate (WPLA). Compos. Part B-Eng. 45-1 (2013) 721-726

9. Frigione, M.: Recycling of PET Bottles as Fine Aggregate in Concrete. Waste Manage. 30-6 (2010) 1101-1106

10. Nikbin, I.M., , Saman Rahimi R., Allahyari,, H., Fallah, F.: Feasibility Atudy of Waste Poly Ethylene Terephthalate (PET) Particles as Aggregate Replacement for Acid Erosion of Sustainable Structural Normal and Lightweight Concrete. J. Clean. Prod. 126 (2016) $108-117$ 
11. Saikia, N., Brito, J.: Mechanical Properties and Abrasion Behaviour of Concrete Containing Shredded PET Bottle Waste as a Partial Substitution of Natural Aggregate. Constr. Build. Mater. 52 (2014) 236-244

12. Albano, C., Camacho, N., Hernandez, M., Matheus, A., Gutierrez, A.: Influence of Content and Particle Size of Waste PET Bottles on Concrete Behavior at Different w/c ratios. Waste Manage. 29 (2009) 2707-2716

13. Correia, J.R., Lima, J.S. Brito, J.: Post-fire Mechanical Performance of Concrete Made with Selected Plastic Waste Aggregates. Cem. Concr. Compos. 53 (2014) 187-199

14. TS EN 197-1.: Cement - Part 1: Composition, Specification and Conformity Criteria for Common Cements. Turkish Standard Institution, Ankara (2012)

15. TS EN 196-1.: Methods of Testing Cement - Part 1: Determination of Strength. Turkish Standard Institution, Ankara (2009)

16. TS EN 1097-6.: Tests for Mechanical and Physical Properties of Aggregates - Part 6: Determination of Particle Density and Water Absorption, Ankara (2013)

17. TS 706 EN 12620+A1.: Aggregates for Concrete. Turkish Standard Institution, Ankara (2009)

18. TS EN 934-2.: Admixtures for Concrete, Mortar and Grout - Part 2: Concrete Admixtures - Definitions, Requirements, Conformity, Marking and Labeling. Turkish Standard Institution, Ankara ( 2011)

19. TS 802.: Design Concrete Mixes. Turkish Standard Institution, Ankara (2009)

20. TS EN 12390-3.: Testing Hardened Concrete - Part 3 : Compressive Strength of Test Specimens. Turkish Standard Institution, Ankara (2010)

21. TS EN 12390-5.: Testing Hardened Concrete - Part 5: Flexural Strength of test Specimens, Ankara (2009)

22. TS 3624.: Test Method for Determination the Specific Gravity the Absorbtion Water and the Void Ratio in Hardened Concrete. Turkish Standard Institution, Ankara (1981)

23. ACI Committee 213R-14.; Guide for Structural Lightweight Aggregate Concrete. Manual of Concrete Practice (2014)

24. Topcu, I.B.: Concrete Technology. Ugur Press, Eskisehir, Turkey (2006). 